\title{
Contribution of ground ice melting to the expansion of Serling Co lake on the Tibetan Plateau
}

Lingxiao Wang ${ }^{1}$, Lin Zhao ${ }^{1,2}$, Huayun Zhou ${ }^{2,3}$, Shibo $\mathrm{Liu}^{2,3}$, Erji $\mathrm{Du}^{2}$, Defu Zou ${ }^{2}$, Guangyue $\mathrm{Liu}^{2}$, Yao Xiao' ${ }^{2}$, Guojie $\mathrm{Hu}^{2}$, Chong Wang ${ }^{1}$, Zhe Sun ${ }^{2}$, Zhibin $\mathrm{Li}^{1}$, Yongping $\mathrm{Qiao}^{2}$, Tonghua $\mathrm{Wu}^{2}$, Chengye $\mathrm{Li}^{1}$, Xubing $\mathrm{Li}^{1}$

${ }^{1}$ School of Geographical Sciences, Nanjing University of Information Science \& Technology (NUIST), Nanjing 210044, China

${ }^{2}$ Cryosphere Research Station on Qinghai-Xizang Plateau, State Key Laboratory of Cryosphere Science, Northwest Institute of Eco-Environment and Resources, Chinese Academy of Sciences (CAS), Lanzhou,

${ }^{3}$ University of Chinese Academy of Sciences, Beijing, China

Correspondence to: Lin Zhao (lzhao@nuist.edu.cn) and Lingxiao Wang (lx.wang@nuist.edu.cn)

Abstract. Serling Co lake, surrounded by permafrost and glacier-occupied regions, has exhibited the greatest increase in water storage over the last 50 years among all the lakes on the Tibetan Plateau. However, increases in precipitation and glacial melting are not enough to explain the increased water volume of lake expansion. The magnitude of the contribution of thawing permafrost to this increase under climate warming remains unknown. This study made the first attempt to quantify the water contribution of ground ice melting to the expansion of Serling Co lake by evaluating the ground surface deformation. We monitored the spatial distribution of surface deformation in the Serling Co basin using the SBAS-InSAR technique and compared it with the findings of field surveys. Then, the ground ice meltwater volume in the watershed was calculated based on the long-term deformation rate. Finally, this volume was compared with the lake volume change during the same period, and the contribution ratio was derived. SBAS-InSAR monitoring during 2017-2020 illustrated widespread and large subsidence in the upstream section of the Zhajiazangbu subbasin, where widespread continuous permafrost is present. The terrain subsidence was normally between 5 and $20 \mathrm{~mm} / \mathrm{a}$, indicating rapid ground ice loss in the region. The ground ice meltwater reached $56.0 \times 10^{6} \mathrm{~m}^{3} / \mathrm{a}$, and the rate of increase in lake water storage was $496.3 \times 10^{6} \mathrm{~m}^{3} / \mathrm{a}$ during the same period, with ground ice meltwater contributing $11.3 \%$ of the lake volume increase. This study is especially helpful in explaining the rapid expansion of Serling Co lake and equilibrating the water balance at the watershed scale. More importantly, the proposed method can be easily extended to other watersheds underlain by permafrost and to help understand the hydrologic changes in these watersheds.

Keywords: surface deformation, SBAS-InSAR, permafrost, ground ice, Serling Co lake, expansion

\section{Introduction}

More than 1000 lakes on the Tibetan Plateau span an area exceeding $1 \mathrm{~km}^{2}$, and the total lake area is greater than $40,000 \mathrm{~km}^{2}$ (Wan et al., 2016). The water in most of these lakes is more or less connected with widely 
have manifested extensive changes (Qiao et al., 2019; Zhang et al., 2020). In particular, Serling Co (Siling Co) lake exhibited the greatest increases in the lake area and water storage: its lake area expanded by $43 \%$ from $1,667 \mathrm{~km}^{2}$ in 1976 to $2389 \mathrm{~km}^{2}$ in 2017 , and its water storage increased by $80 \%$ from $309.4 \times 10^{8} \mathrm{~m}^{3}$ in 1972 to $558.4 \times 10^{8} \mathrm{~m}^{3}$ in 2017 (Yang et al., 2017; Zhu et al., 2019). Its lake area surpassed Nam Co lake in 2014 and is now the second largest saltwater lake in China. Such rapid changes in Serling Co lake have exerted significant effects on the regional environment and have attracted substantial interest within the scientific community.

The entire Serling Co watershed covers a drainage area of $4.4 \times 10^{4} \mathrm{~km}^{2}$ and hosts 642 glaciers with a total area of $593.1 \mathrm{~km}^{2}$ and ice reserves of $36.4 \mathrm{~km}^{3}$ (Bian et al., 2010; Shi et al., 2005). The watershed has a large permafrost distribution, including both continuous permafrost and seasonally frozen ground covering an area of $1.3 \times 10^{4} \mathrm{~km}^{2}$, with the former being widespread mainly in the northern part of the watershed (Zou et al., 2017). Based on a map of the ground ice distribution across the Qinghai-Tibet Plateau, the ground ice volume in the watershed reaches $132.3 \mathrm{~km}^{3}$ (Zhao and Sheng, 2019). To reveal the potential reasons for the abovementioned rapid expansion of lakes on the plateau, an accurate estimation of the basin water balance is urgent (Lei et al., 2014; Zhang et al., 2017; Li et al., 2014; Song et al., 2014). Glacial meltwater, the thawing of permafrost, precipitation (including snow) and changes in evapotranspiration all contribute to lake recharge. A model simulation of endorheic basins on the Tibetan Plateau showed that increased net precipitation contributed the majority of the water supply $(\sim 70 \%)$ for the increased lake volume (Zhang et al., 2017). In addition, recent research has revealed that glacial meltwater contributed $\sim 10 \%$ of the total water input to Serling Co lake since the 1970s (Lei et al., 2013; Tong et al., 2016). The weakening of lake evaporation has also contributed to the accelerated expansion of Serling Co lake to some extent, but this contribution is small (Guo et al., 2019). In contrast, the contribution of thawing permafrost to lake expansion remains poorly quantified.

60

Significant permafrost degradation has been observed on the Tibetan Plateau under a warming climate. The monitoring of ten boreholes on the Tibetan Plateau revealed that from 1981 to 2018, the active layer thickened at an average rate of $19.5 \mathrm{~cm}$ per decade; moreover, this thickening has been accelerating in recent years (Zhao et al., 2020). The thawing of the ice-rich permafrost layer just below the permafrost table releases a certain amount of water into the hydrological cycle (Zhao et al., 2019). Some studies have suggested that permafrost degradation might be a possible source of the water that is causing lakes to expand (Li et al., 2014), but this contribution has yet to be quantified. Under the dramatic hydrometeorological changes observed in recent decades, quantifying the contribution of thawing permafrost is not an easy task. Some researchers calculated the contributions of meltwater from ground ice to surface water runoff by separating hydrographs using isotopes and found that the contribution ranged from $13.2 \%$ to $16.7 \%$ in the source region of the Yellow River (Yang et al., 2019), and that to nearby thermokarst lakes in the Beiluhe region reached 61.3\% (Yang et al., 2016). Some studies estimated the meltwater from permafrost degradation by modeling 
the active layer thickening rate and then multiplying the result by the average ground ice content (Zhang et al., 2017).

The ice content within the uppermost layer of permafrost is typically higher than the saturated water content after this permafrost layer thaws; hence, the thawing of this layer might result in the terrain settlement (Streletskiy et al., 2016; Shiklomanov et al., 2013), slumping, or collapse of the ground surface (Günther et al., 2015; Lantuit and Pollard, 2008; Kokelj and Jorgenson, 2013). Interferometric synthetic aperture radar (InSAR) analysis can exploit the phase changes in SAR signals to determine the relative surface displacement on the order of millimeters to centimeters. Accordingly, InSAR monitoring can detect the terrain subsidence triggered by the thawing of ice-rich permafrost, e.g., (Daout et al., 2020), (Zwieback and Meyer, 2021), (Chen et al., 2018),(Lu et al., 2020), (Liu et al., 2012). Permafrost regions with higher ground ice contents have been shown to produce greater terrain subsidence on the Tibetan Plateau (Wu et al., 2018; Daout et al., 2017; Chen et al., 2018). The long-term subsidence rate is less than $5 \mathrm{~mm} / \mathrm{a}$ on the northwestern Tibetan Plateau, where the climate is cold and dry (Daout et al., 2017), while it ranges from 3 to $30 \mathrm{~mm} / \mathrm{a}$ on the ice-rich Eboling Mountain in the northeastern region of the Tibetan Plateau (Chen et al., 2018). Such long-term terrain subsidence in permafrost regions is mostly the consequence of the thawing of the ice-rich permafrost layer under warming climate conditions (Zhao et al., 2019).

90

In this study, we present the first attempt to quantify the contribution of melting ground ice to the expansion of the Serling Co watershed. We hypothesize that the long-term ground subsidence in this watershed is related to the subsurface depth of ground ice melting. The spatial distribution of surface deformation was derived through InSAR analysis and compared with the findings of field surveys. Finally, the ground ice meltwater volume in the watershed was compared with the Serling Co lake volume increase, and the contribution ratio was determined.

\section{Study area and data resources}

\subsection{Study area}

The Serling Co watershed, which is in the transitional zone between the Indian monsoon and the westerlies over the Tibetan Plateau, is situated in a cold semiarid monsoon climate with a mean annual temperature of approximately $0^{\circ} \mathrm{C}$, an average precipitation of $\sim 350 \mathrm{~mm}$ (Tong et al., 2016). From 1979 to 2017, the average annual temperature increased at a rate of $0.049^{\circ} \mathrm{C} / \mathrm{a}$, and the average annual precipitation increased at a rate of $4.65 \mathrm{~mm} / \mathrm{a}$, with the main increase occurring after the mid-1990s (Zhu et al., 2019).

105 This watershed basin extends over a total area of approximately $4.4 \times 10^{4} \mathrm{~km}^{2}$, and the rivers and lakes within the basin are connected, forming an inland lake group. Ngoin Co is located south of Serling Co, while Wuru Co \& Qiagui Co are located west of Serling Co; their locations are marked as (2) and (3), respectively, in 
Fig. 1. The main rivers entering the lake are the Zhajiazangbu (from the north into the lake), Zhagenzangbu (west), Alizangbu (west), and Boquzangbu (east) (Tong et al., 2016), as shown in Fig. 1. The details of the

110 four major subbasins and the inflows of the runoff from these rivers into the lake are listed in Table 1. The Zhajiazangbu river with a length of $409 \mathrm{~km}$ originates from the Tanggula Mountains and enters Serling Co lake from the north. Widespread continuous permafrost occurs mainly in the northern part of the basin, whereas sporadic permafrost and seasonally frozen ground are found in the central and southern parts of the watershed. Among the four subbasins, the Zhajiazangbu has the largest permafrost distribution $\left(10667 \mathrm{~km}^{2}\right.$,

$11566.2 \%$ of the subbasin area), followed by the Zhagenzangbu $\left(1967 \mathrm{~km}^{2}, 12.3 \%\right.$ of the subbasin area) (Zou et al., 2017).

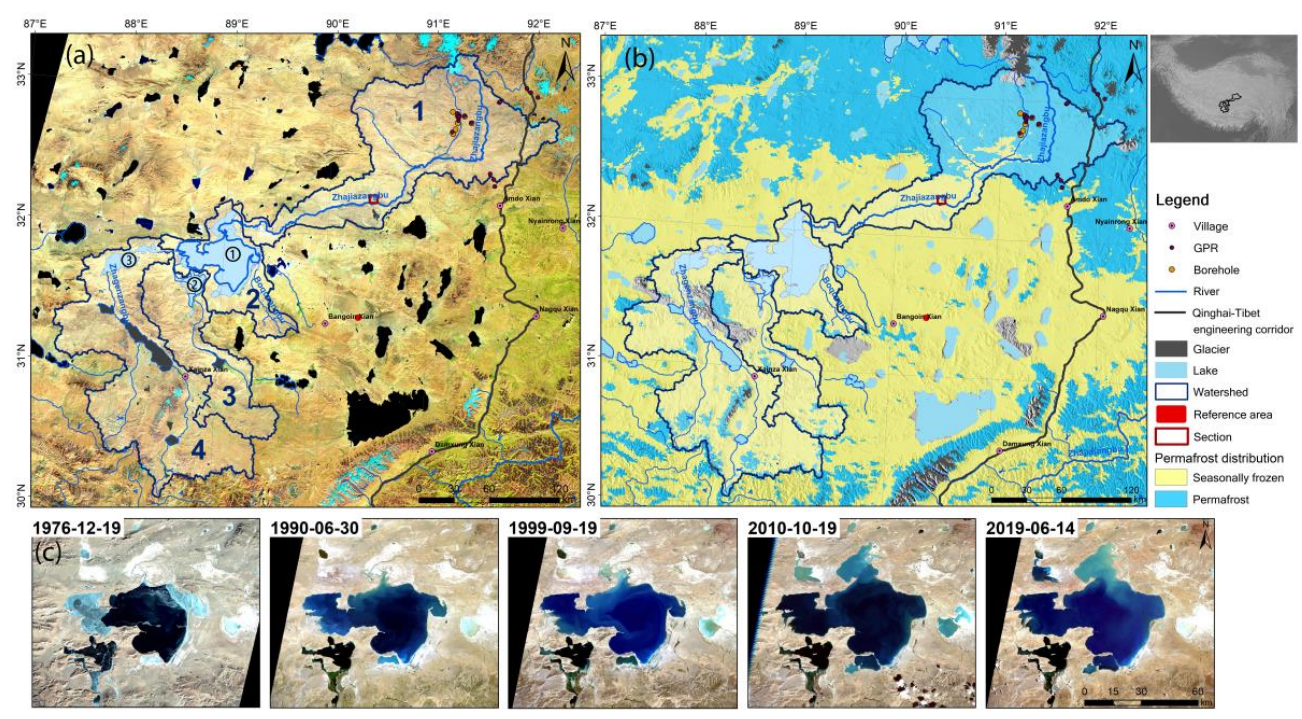

Figure 1 Study area. The base map in Fig. 1(a) is a Landsat 8 image acquired in October 2020 (red: SWIR1, green: NIR, blue: red). The base map in Fig. 1(b) is a permafrost map (Zou et al., 2017); the hillshade is calculated using a 1-arcsec SRTM DEM with the Sentinel-1 incidence angle and azimuth angle. The red dot marks the position of our InSAR reference point. The locations of the GPR surveys and boreholes are shown with dots. Fig. 1(c) shows the lake areas from 1976 to 2019 on Landsat optical images.

Table 1 Characteristics of the Serling Co lake basin.

\begin{tabular}{|c|c|c|c|c|c|c|}
\hline \multirow{2}{*}{\multicolumn{2}{|c|}{ Basin }} & \multirow[t]{2}{*}{ Area $\left(\mathbf{k m}^{2}\right)$} & \multirow{2}{*}{$\begin{array}{l}\text { Ave. } \\
\text { elevation (m) }\end{array}$} & \multicolumn{3}{|c|}{ Permafrost coverage } \\
\hline & & & & Area $\left(\mathrm{km}^{2}\right)$ & $\begin{array}{l}\text { Percentage of } \\
\text { subbasin area } \\
(\%)\end{array}$ & $\begin{array}{l}\text { Percentage of } \\
\text { entire basin area } \\
(\%)\end{array}$ \\
\hline 1 & Zhajiazangbu subbasin & 16112 & 4963 & 10667 & 66.2 & 24 \\
\hline 2 & Boquzangbu subbasin & 5474 & 4651 & 124 & 2.3 & 0.3 \\
\hline
\end{tabular}


https://doi.org/10.5194/tc-2021-335

Preprint. Discussion started: 22 November 2021

(c) Author(s) 2021. CC BY 4.0 License.

\begin{tabular}{llccccc}
\hline $\mathbf{3}$ & Alizangbu subbasin & 6831 & 4951 & 646 & 9.5 & 1.5 \\
\hline $\mathbf{4}$ & Zhagenzangbu subbasin & 16019 & 5022 & 1967 & 12.3 & 4.4 \\
& & & & & 30.2
\end{tabular}

\subsection{Field data}

We conducted a field investigation of the permafrost in the study area during the autumn months of 2019 . During the fieldwork, we drilled seven boreholes and carried out ground penetrating radar (GPR) surveys.

Boreholes with depths deeper than $20 \mathrm{~m}$ were drilled in the upstream section of the Zhajiazangbu subbasin; their locations are marked in Fig. 1, and their descriptions are provided in Table 2. Field photographs of cores at borehole sites SLC01 and SLC04 are shown in Fig. 2.

Twenty 50-m-long GPR profile surveys were carried out within or around the catchment, fourteen of which were within the basin. Based on the fourteen GPR reflection profiles carried out within the basin, the permafrost active layer has a maximum thickness of $4.1 \mathrm{~m}$, a minimum of $2.0 \mathrm{~m}$, and an average value of 3.2 $\mathrm{m}$. The volumetric soil water content in the active layer ranges from a maximum of $46.4 \%$ to a minimum of $14.7 \%$, with an average of $22.6 \%$ based on GPR interpretation.
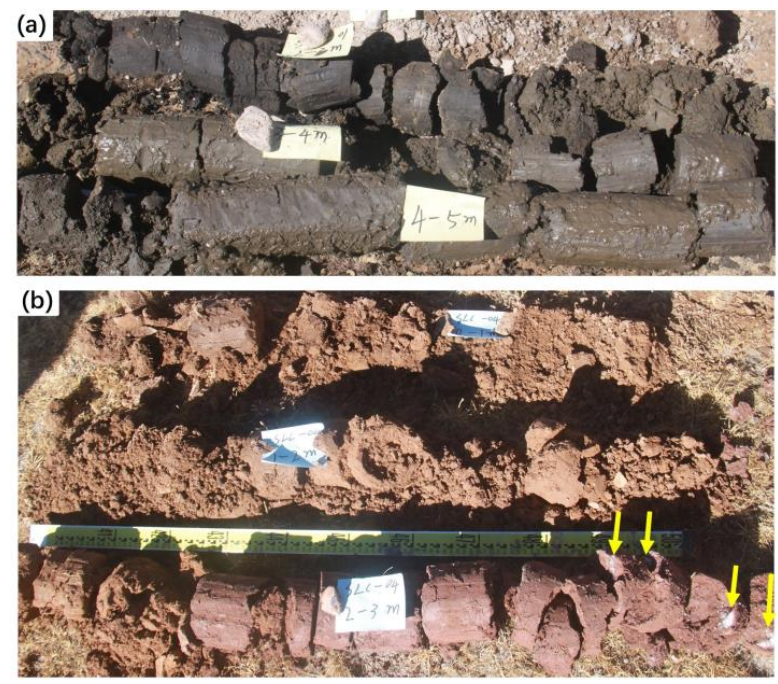

Figure 2 Cores from borehole SLC01 at depths of 2-55 m (a) and SLC04 at depths of 0-3 m (b). Ice blocks were found in SLC04 at a depth of $2.4 \mathrm{~m}$, as indicated by the arrows in (b). 
https://doi.org/10.5194/tc-2021-335

Preprint. Discussion started: 22 November 2021

(c) Author(s) 2021. CC BY 4.0 License.

Table 2 Borehole properties.

\begin{tabular}{|c|c|c|c|c|c|c|}
\hline Site & $\begin{array}{l}\text { Ele. } \\
\text { (m) }\end{array}$ & $\begin{array}{l}\text { Type of frozen } \\
\text { ground }\end{array}$ & $\begin{array}{l}\text { Permafrost } \\
\text { table (m) }\end{array}$ & Topography & Surface & $\begin{array}{l}\text { Development of } \\
\text { ground ice }\end{array}$ \\
\hline SLC01 & 4934 & permafrost & 3.0 & floodplain & $\begin{array}{l}\text { alpine meadow } \\
\text { veg coverage: } 40 \% \text {, } \\
\text { surface soil is sandy, dry }\end{array}$ & Not found \\
\hline SLC02 & 4999 & permafrost & 3.6 & river terrace & $\begin{array}{l}\text { degraded alpine steppe, } \\
\text { sparse vegetation, } \\
\text { surface soil is sandy, dry }\end{array}$ & $\begin{array}{l}\text { ice at depths of } \\
3.6-5.5 \mathrm{~m}\end{array}$ \\
\hline SLC03 & 4986 & permafrost & 3.0 & river valley & $\begin{array}{l}\text { alpine swamp meadow, } \\
\text { veg coverage: } 90 \% \\
\text { high water content in the } \\
\text { active layer }\end{array}$ & $\begin{array}{l}\text { ice at } 2.4-3.0 \mathrm{~m} \text {, } \\
\text { large amounts of } \\
\text { liquid water found } \\
\text { at } 3.0-4.5 \mathrm{~m} \text {, ice } \\
\text { lenses at } 4.6-5.1 \\
\mathrm{~m}\end{array}$ \\
\hline SLC04 & 4909 & permafrost & $<2.4$ & $\begin{array}{l}\text { river valley terrace, } \\
\text { approximately } 500 \\
\mathrm{~m} \text { away from the } \\
\text { river }\end{array}$ & $\begin{array}{l}\text { alpine swamp meadows } \\
\text { veg coverage: } 90 \%\end{array}$ & $\begin{array}{l}\text { ice at } 2.4 \mathrm{~m} \text {, pure } \\
\text { ice layer }(\sim 3 \mathrm{~cm}) \\
\text { at } 4.2-4.3 \mathrm{~m} \text {, and } \\
\text { ice lenses at } 6-7.7 \\
\mathrm{~m}\end{array}$ \\
\hline SLC05 & 4871 & $\begin{array}{l}\text { seasonally } \\
\text { frozen ground }\end{array}$ & NA & $\begin{array}{l}\text { river valley in } \\
\text { between two rivers }\end{array}$ & $\begin{array}{l}\text { alpine steppe } \\
\text { veg coverage: } 30 \% \text {, } \\
\text { surface soil is sandy and } \\
\text { contains abundant gravel }\end{array}$ & Not found \\
\hline SLC06 & 5059 & permafrost & Unclear & top of slope & $\begin{array}{l}\text { alpine meadow } \\
\text { veg coverage: } 50 \% \text {, } \\
\text { surface soil is sandy and } \\
\text { contains abundant gravel }\end{array}$ & ice at $6-7.8 \mathrm{~m}$ \\
\hline SLC07 & 4943 & permafrost & Unclear & $\begin{array}{l}\text { middle of a very } \\
\text { gentle slope }\end{array}$ & $\begin{array}{l}\text { degraded alpine meadow, } \\
\text { very sparse veg } \\
\text { surface soil is sandy and } \\
\text { contains abundant gravel, } \\
\text { severely salinized }\end{array}$ & $\begin{array}{l}\text { liquid water found } \\
\text { at } 2.5-6.5 \mathrm{~m} \text { and a } \\
\text { large amount at } \\
2.5-3.5 \mathrm{~m}\end{array}$ \\
\hline
\end{tabular}

\subsection{Sentinel-1 SAR images}

150 Sentinel-1 (S1) C-band SAR images (https://scihub.copernicus.eu/) were used to monitor the surface deformation. Sentinel-1 is a C-band SAR mission that was launched in 2014 (S1A) and 2016 (S1B). It is a constellation of two satellites orbiting the earth and has been developed and operated by the European Space Agency (ESA) within the Copernicus program. Level 1 single look complex (SLC) images of interferometric 
https://doi.org/10.5194/tc-2021-335

Preprint. Discussion started: 22 November 2021

(C) Author(s) 2021. CC BY 4.0 License.

wide-swath (IW) mode with VV polarization in the descending orbit were used in the study. The study area covers two orbits of S1 acquisitions, and the details are shown in Table 3. In total, 95 acquisition dates for orbit 48 and 100 acquisition dates for orbit 150 from September 2017 to December 2020 were processed.

Table 3 Information on Sentinel-1 images processed to monitor surface deformation.

\begin{tabular}{lll}
\hline & Orbit 48 & Orbit 150 \\
\hline Frame & $489,484,479$ & $490,485,480$ \\
\hline Incidence angle (degree) & $31.85-46.32$ & $31.57-46.27$ \\
\hline Acquisition period & $2017-09-11$ to 2020-12-24 & $2017-09-05$ to 2020-12-30 \\
\hline Number of acquisition dates & 95 & 100 \\
\hline
\end{tabular}

\subsection{SRTM DEM}

A 1-arcsecond grid ( 30-m) Shuttle Radar Topographic Mission (SRTM) digital elevation model (DEM) was used to calculate the slope and to remove the topographic phase and implement geocoding during InSAR processing.

\subsection{ICESat-2 dataset}

165 Laser altimetry data of ICESat-2 ATL13 (https://nsidc.org/data/atl13) were applied to extract the water surface elevation of the lakes.

\subsection{Landsat 8 OLI images}

Landsat 8 OLI optical images (https://glovis.usgs.gov/) were used to detect lake extent changes. Images acquired during autumn or summer with no influence of the cloud were selected. The acquisition dates and path/row of these images are listed in Table 4.

Table 4 Information on the Landsat 8 images used.

\begin{tabular}{lllllll}
\hline Lake & $\mathbf{2 0 1 5}$ & $\mathbf{2 0 1 6}$ & $\mathbf{2 0 1 7}$ & $\mathbf{2 0 1 8}$ & $\mathbf{2 0 1 9}$ & $\mathbf{2 0 2 0}$ \\
\hline Serling Co & p140r037_20 & p139r038_20 & p139r038_20 & p139r038_20 & p139r038_20 & p139r038_20 \\
& 151117 & 161112 & 170928 & 181001 & 190614 & 201006 \\
\hline Ngoin Co & p140r038_20 & p139r038_20 & p139r038_20 & p140r038_20 & p140r038_20 & p140r038_20 \\
& 150930 & 16112 & 170928 & 181109 & 190925 & 201013 \\
\hline Wuru Co & $\mathbb{\&} 140 \mathrm{p}$ r038_20 & p140r038_20 & p140r038_20 & p140r038_20 & p140r038_20 & p140r038_20 \\
Qiagui Co & 150930 & 161103 & 171005 & 181109 & 190925 & 201013
\end{tabular}

"p" denotes the path and " $r$ " denotes the row of the frame 


\section{Methodology}

\subsection{Workflow}

An overview of the methodology in this study is illustrated in Fig. 3. The main steps are summarized as i) retrieval of lake water storage changes, ii) retrieval of deformation time series, iii) estimation of the ground ice meltwater volume from the long-term deformation rate, and iv) calculation of the ratio of the water volume contributed by permafrost ground ice melting to the increase in lake water storage. The detailed processing steps are described in the following subsections.

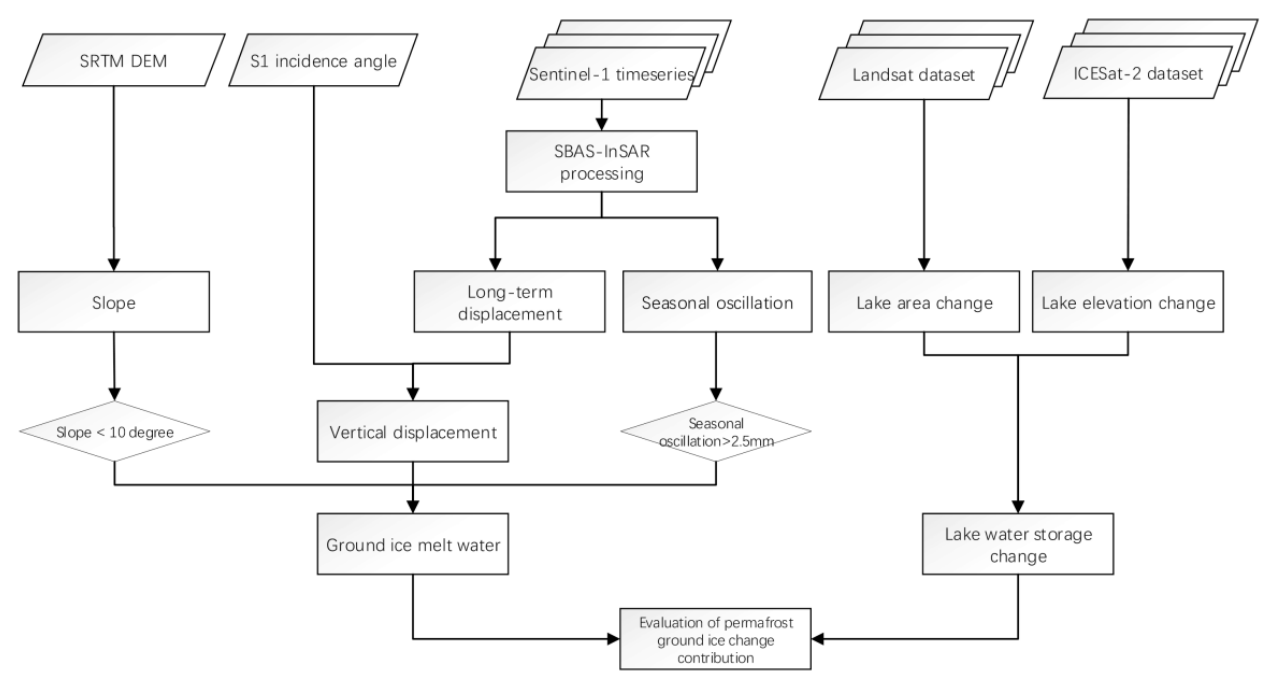

185 Figure 3 Workflow of estimating the water contribution of permafrost ground ice melting to the expansion of Serling Co lake.

\subsection{Lake water storage change}

First, we retrieved the surface water level elevation through the laser altimetry ICESat-2 ATL13 product.

Data values within the lake area were extracted from 13 October 2018 to the end of 2020. For each year, the mean annual value was calculated from all data acquisitions during the year. The lake water level change rate was then estimated by a linear trend model.

Then, we extracted the lake area extent using Landsat 8 OLI images in 2018, 2019, and 2020. Three bands

195 (NIR, SWIR1, and SWIR2) were stacked to extract the lake area because lake water has extremely low reflectance at these bands and thus is easily separated from other land cover types. K-means clustering was then applied to classify the stacked image into two classes: water and other land covers. After that, a $3 \times 3$ window size majority filtering was applied as a postprocessing step, and we then converted the classified image to the shapefile and eliminated the spots outside the inlet and outlets of the lake. The lake areas in 

the same inlets and outlets. For lakes with irregular areas, their storage can be approximately calculated according to the volume of the circular platform, and then the volume change of the lake can be calculated from the difference between the volumes of two circular platforms (Zhang et al., 2019a), as described in Eq. (1):

where $\Delta \mathrm{V}$ is the change in lake water storage, $S_{1}$ and $S_{2}$ represent the lake areas of two periods (e.g., the lake areas in 2018 and 2020), and $\left(H_{2}-H_{1}\right)$ represents the lake level change between the two periods.

\subsection{Deformation monitoring}

\subsubsection{SBAS-InSAR processing}

210 Time series InSAR analysis was implemented using small baseline subset (SBAS) analysis, which deploys multiple master datasets to minimize the effects of spatial-temporal decorrelation (Berardino et al., 2002; Lanari et al., 2004; Usai, 2003) by selecting interferograms having small spatial and temporal baselines. Thus, this technique is suitable for permafrost environments prone to strong spatial-temporal decorrelation.

The Serling Co basin covered two orbits of S1 images. We processed the SBAS-InSAR analysis individually

215 for each orbit. SBAS-InSAR processing in this study contains three main steps: i) InSAR processing of the images, including interferogram network selection, coregistration, differential interferogram phase generation and phase unwrapping; ii) deformation time series estimation; and iii) reference point refinement and geocoding.

220 The main processing steps are described as follows:

i) InSAR Processing

Every SAR image was coregistered with the next two sequential acquisitions. The precision state vectors obtained from the ESA were applied to reduce the effects of inaccurate baselines. To overcome the decorrelation caused by permafrost landscapes (mainly vegetation dynamics) and terrain elevation changes, we generated only interferograms with short time intervals. The temporal baselines of individual interferograms are 12 to 24 days, and the perpendicular baseline of all the interferometric pairs is $<100 \mathrm{~m}$. We then performed multilooking with 3 pixels in range and 13 pixels in azimuth to form a square pixel ( 40 $\mathrm{m}$ ) and reduce the noise. To remove the topographic phase, the topographic phase was simulated using the SRTM DEM and subtracted from the interferogram. After that, we applied an adaptive spectral filter to produce differential interferograms. To unwrap the differential phase, a minimum cost flow (MCF) phase unwrap method was applied. Two orbits covering an area of approximately $450 \mathrm{~km} \times 500 \mathrm{~km}$ were processed. This processing was implemented using ISCE (https://github.com/isce-framework/isce2). Coregistration and conversion between radar coordinates and geometric coordinate systems were accelerated by the aid of a graphic processing unit (GPU) under the CUDA framework during the processing of such a large area. 
In this step, the network of unwrapped interferograms was inverted to construct a timeline of line-of-sight (LOS) displacement maps. We applied a weighted least square (WLS) estimator to invert the network of interferograms into time series. During the inversion, interferograms are weighted by the inverse of the phase variance (Guarnieri and Tebaldini, 2008; Tough et al., 1995). Different from some studies conducted in permafrost environments that presuppose deformation models to facilitate solving the phase time series, we did not preset any deformation and obtained the raw phase time series by minimizing the phase residual. The time series of LOS displacements are relative to the first scene of the datasets and spatially relative to the reference point. The reference point was firstly set by selecting pixels with extremely high temporal coherence greater than 0.99 . After the raw phase time series were obtained, the tropospheric delay correction, phase deramping, and topographic residual correction were applied. The tropospheric delay was estimated in the satellite LOS direction using ERA-5 reanalysis data. The processing was conducted in PyAPS software (Jolivet et al., 2014). Linear phase ramps, which might be caused by residual tropospheric and ionospheric delays, were estimated and removed from the displacement time series at each acquisition using reliable pixels. The systematic topographic phase residuals caused by DEM errors were estimated based on the proportionality with the perpendicular baseline time series (Fattahi and Amelung, 2013). The processing described above was implemented by MintPy (Zhang et al., 2019b) (https://github.com/insarlab/MintPy).

iii) Reference point refinement and geocoding

In the natural environment, the exposed bedrock in flat terrain is normally selected as the reference point; however, because such exposed bedrock is scarce in the study area, we took great care in the selection of reference points. We selected a reference point outside the permafrost region in very dry and flat terrain. The reference area was homogeneous and had interferometric coherence close to 1 . We adjusted the displacements relative to this reference area. The location of the reference area is marked in Fig. 1. Finally, we geocoded the deformation time series to the WGS84 coordinate system with $0.0005 \times 0.0005$ degree spacing and then reprojected it to the Albers equal area conic system with a $100 \times 100 \mathrm{~m}$ grid size.

\subsubsection{Extraction of the periodic (seasonal) amplitude and long-term rate}

The surface deformation in the permafrost terrain exhibits characteristics of both long-term linear deformation and seasonal oscillation (upheaval in winter and spring and subsidence in summer and autumn) (Daout et al., 2017; Li et al., 2015). We used a sinusoidal seasonal function plus a linear trend to the displacement time series of each image pixel using Eq. (2). To minimize the effect of extreme values, we also applied a 3 -size moving window filter to the deformation time series.

$d(t)=\mathrm{a} \cdot t+A \cdot \sin \left(\frac{2 \pi}{T} \cdot t+\varphi\right)+\mathrm{c}$

where $t$ is the time interval with respect to the first SAR image acquisition date, a is the long-term rate, A is the periodic (seasonal) amplitude, $T$ is the period of the seasonal undulations (assumed to be one year), $\varphi$ is the initial phase, and $\mathrm{c}$ is the residual term. $\mathrm{a}, A, \varphi$ and $\mathrm{c}$ are the coefficients to be determined.

For each orbit, we extracted the periodic (seasonal) amplitude and long-term rate pixel by pixel from the deformation time series and then mosaiced the results from the two orbits together. 


\subsubsection{Deformation from LOS to vertical direction}

For the flat terrain, deformation is mainly caused by freeze-thaw permafrost activity and is mainly in the vertical direction. Thus, the observed deformation is the terrain movement projection in the LOS direction. The observed deformation in the LOS direction was converted to the vertical direction using Eq. (3) by dividing the deformation value by the cosine of the incidence angle. The incidence angle ranges of orbit 48 and orbit 150 of the $\mathrm{S} 1$ sensor are listed in Table 1.

$d_{v}=d_{L O S} / \cos (\theta)$

where $d_{L O S}$ is the observed deformation along the line of the sight, $d_{v}$ is the deformation in the vertical direction, and $\theta$ is the incidence angle of the sensor.

\subsection{Conversion from ground deformation to ground ice meltwater contribution}

A considerable amount of ground ice is always buried in permafrost regions, especially just below the permafrost table; this ice forms mostly by ice segregation during the long permafrost formation process (Cheng, 1983; Mackay, 1983; French and Harbor, 2013). Thawing of the uppermost permafrost layer is always accompanied by the compaction of sediment and subsidence of the ground surface due to the melting of super-saturated ground ice (French, 2017). Hence, the higher the ice content in permafrost that melts under the warming climate, the larger the surface subsidence that occurs as a result. In this study, we assume that the long-term subsided height in elevation is equal to the thickness of ground ice that melts. We converted the deformation rate into the ground ice meltwater following these steps:

290 i) masking off areas with slope angles $>10^{\circ}$

On steep slopes, the deformation occurs mainly as downslope movements driven by gravity (Buckel et al., 2021; Reinosch et al., 2020); thus, we considered only areas with slope angles below $10^{\circ}$. The threshold of $10^{\circ}$ was adopted based on previous works (Reinosch et al., 2020; Buckel et al., 2021).

ii) masking off areas with the LOS direction periodic (seasonal) amplitudes or long-term velocities $\leq 2.5 \mathrm{~mm}$

The threshold of $2.5 \mathrm{~mm}$ was set based on previous works (Daout et al., 2017; Buckel et al., 2021). A periodic seasonal threshold was used to mask off areas that are not affected by permafrost activity (because they do not experience periodic frost heave and thaw subsidence) but exhibit continuous sedimentary uplift or subsidence. Areas with periodic (seasonal) oscillations in the amplitude and long-term (interannual) velocities less than $2.5 \mathrm{~mm}$ are likely unmoving considering distortions in the InSAR phase and DEM error.

iii) conversion from ground deformation into ground ice meltwater

Serling Co lake is located in the lowest area of the watershed, and the water released from thawing permafrost eventually enters the lake. The long-term deformation represents the elevation changes produced by the ground ice change. Using Eq. (4), by multiplying the grid cell size, we can obtain the ice volume change for each grid cell and then sum them to estimate the total ice volume amount. Because the density of water is $\sim 1.0 \mathrm{~g} / \mathrm{cm}^{3}$ and that of ice is $\sim 0.91 \mathrm{~g} / \mathrm{cm}^{3}$, the ice volume amount is then multiplied by actor of 0.91 to convert to the water volume.

$\Delta V_{\text {water }}=0.91 \cdot \Delta V_{\text {ice }}=0.91 \cdot \sum \Delta h \cdot C_{\text {grid }}=0.91 \cdot \sum d \cdot C_{\text {grid }}$ 
where $\Delta V_{\text {ice }}$ is the change in ground ice volume, $\Delta h$ is the elevation change produced by the ice change, $C_{\text {grid }}$ is the area of a grid cell, and $d_{v}$ is the long-term deformation in the vertical direction.

\section{Results}

\subsection{Lake water storage change}

We analyzed the lake storage changes in three large lakes within the large Serling Co watershed: Serling Co, Ngoin Co, and the combination of Wuru Co \& Qiagui Co. Fig.4 illustrates the time series of lake elevation of investigated lakes during October 2018 and 2020 derive by ICESat-2. The surface extents and elevation changes of these three lakes are summarized in Table 5 and Table 6. From 2015 to 2020, Serling Co expanded at a rate of $10.3 \mathrm{~km}^{2} / \mathrm{a}$. Limited by the data acquisition period of ICESat-2, which was launched in 2018, we can confirm only that the surface water increased at a rate of $0.2 \mathrm{~m} / \mathrm{a}$ for Serling Co during 2018-2020. Calculated by changes in the lake area and height using Eq. (1), the lake water storage from 2018 to 2020 increased by $496.3 \times 10^{6} \mathrm{~m}^{3} / \mathrm{a}$.

Table 5 Lake area from 2015 to 2020.

\begin{tabular}{|c|c|c|c|c|c|c|c|}
\hline \multirow[t]{2}{*}{ Lake } & \multicolumn{7}{|c|}{ Area $\left(\mathbf{k m}^{2}\right)$} \\
\hline & 2015 & 2016 & 2017 & 2018 & 2019 & 2020 & $\begin{array}{l}\text { Change velocity } \\
\left(\mathrm{km}^{2} / \mathrm{a}\right)\end{array}$ \\
\hline Serling Co & 2398.7 & 2377.1 & 2393.8 & 2408.1 & 2421.1 & 2441.2 & 10.3 \\
\hline Ngoin Co & 276.6 & 276.7 & 281.8 & 281.6 & 285.2 & 284.1 & 1.8 \\
\hline Wuru Co \& Qiagui Co & 432.5 & 437.2 & 432.5 & 452.5 & 447.2 & 443.0 & 2.9 \\
\hline
\end{tabular}
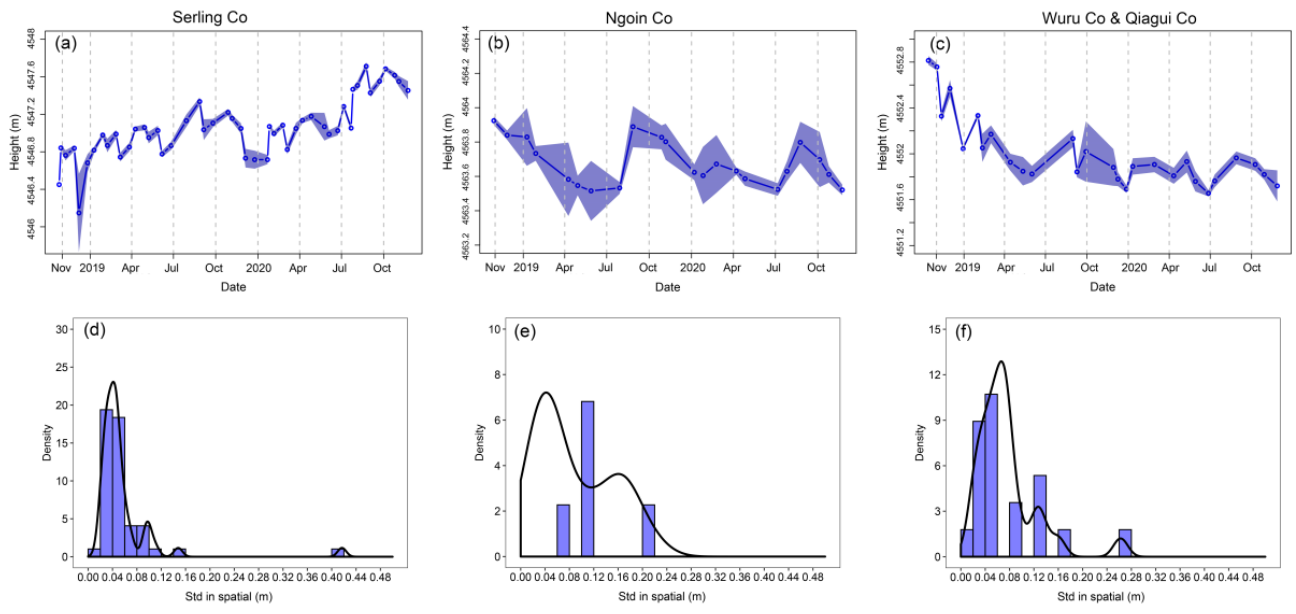

Figure 4 Lake elevation from three lakes. Subfigures (a)-(c) are elevations derived from ICESat-2, in which the solid lines indicate the average values of all elevation measurements within the lake on a given date, and the light- 
Table 6 Lake elevation from 2018 to 2020.

\begin{tabular}{|c|c|c|c|c|c|}
\hline \multirow[t]{2}{*}{ Lake } & \multicolumn{5}{|c|}{ Surface water elevation (m) } \\
\hline & 2018 & 2019 & 2020 & $\begin{array}{l}\text { Change } \\
(\mathrm{m} / \mathrm{a})\end{array}$ & velocity \\
\hline Serling Co & 4546.77 & 4546.99 & 4547.18 & 0.20 & \\
\hline Ngoin Co & 4563.85 & 4563.77 & 4563.68 & -0.09 & \\
\hline Wuru Co \& Qiagui Co & 4552.50 & 4552.04 & 4551.89 & -0.30 & \\
\hline
\end{tabular}

\subsubsection{Deformation time series}

Fig. 5 shows the time series at five sites within a small $(6.5 \mathrm{~km} \times 6.5 \mathrm{~km})$ region where the surface is flat and the elevation is lower than the Zhajiazangbu upstream region. For a better demonstration, this section is marked in Fig. 1. In this area, the mean annual air temperature is $-2.0^{\circ} \mathrm{C}$, calculated based on ERA5-Land air temperature hourly reanalysis data during 2017-2020. Sites 1-4 exhibit strong seasonal oscillations, whereas site 5 does not. As seen from Fig. 5(a), site 5 has almost no vegetation cover, and the surface is dry. The low water storage in the active layer explains its low seasonal amplitude because the seasonal deformation is mainly affected by the water content in the active layer due to the ice-water phase change in the active layer during the freeze-thaw cycle. Both subsidence and uplift signals are detected within the small extent of Fig. 5(a). The subsidence is the result of ground ice melting. The uplift signals of site 1 and site 4 are worth exploring. These signals might be related to ground ice aggradation; as shown in Fig. 5(a), they are very close to the streams, and a sufficient water supply accompanied by strong evaporation (cooling effect, energy is taken away) might facilitate the upward freezing of previously unfrozen (or seasonally frozen) sediment. Alternatively, the uplift signal might be related to alluvial sedimentation or groundwater table rise. However, in the area of Fig. 5(a), the uplift signal has a high possibility of being related to ground ice aggradation since the seasonal amplitude is very large. This phenomenon has been discussed by (Daout et al., 2020), who also found the coexistence of ground subsidence and uplift and speculated that excess meltwater pools and triggers an increase in segregation ice near the permafrost table. 

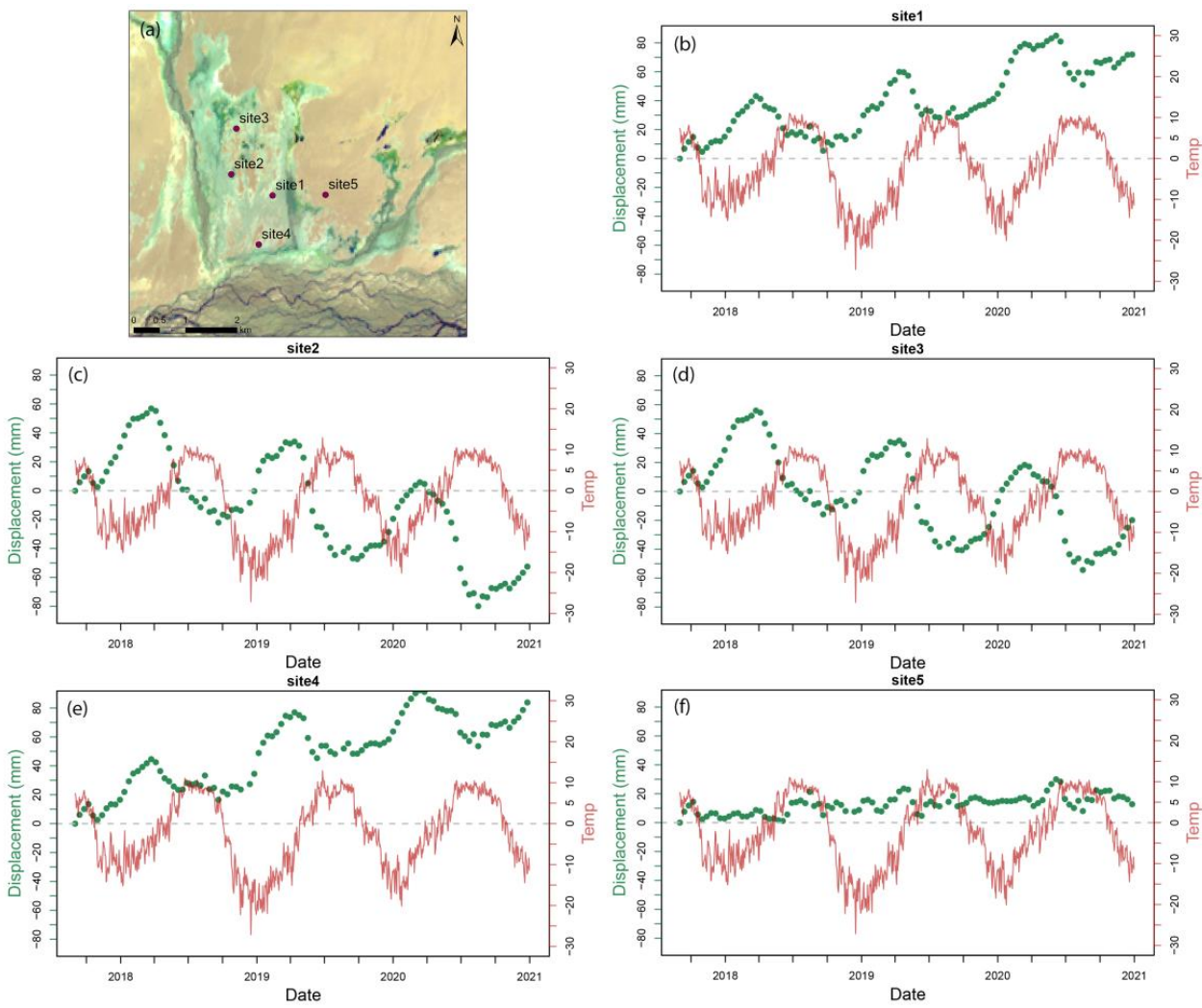

Figure 5 Deformation time series in the sector marked with the red rectangle in Fig. 1. Positive values represent uplift and negative values represent subsidence relative to the first scene of the $\mathrm{S1}$ datasets. Air temperature in red color is from ERA5-Land air temperature hourly reanalysis data.

\subsubsection{Spatial distributions of the seasonal amplitude and long-term rate}

Fig. 6 and Fig. 7 show the spatial distributions of the long-term deformation rate and seasonal amplitude, respectively. The Serling Co basin spanned two orbits of Sentinel-1 images: orbit 48 and orbit 150 . We extracted the seasonal and trend signals from the two orbits and mosaiced them together. The two results from orbit 150 and orbit 48 coincide with each other very well in the overlapping area, and we did not find any breaks or jumps in the place of stitching. This confirmed that the seasonal amplitudes and rate signals extracted from the two orbits are robust, although the acquisitions of the two orbits are not the same (Table $3)$.

The spatial distributions of both the seasonal amplitude and the long-term deformation rate are in accordance with the permafrost distribution map (Fig. 1). The boundary differentiating continuous permafrost from seasonally frozen ground in Fig. 1 exactly delineates the spatial distribution of the long-term deformation 
rate in Fig. 6 and that of the seasonal amplitude in Fig. 7. As shown in Fig. 6, widespread and large magnitudes of subsidence and large seasonal amplitudes are located in the upstream portion of the Zhajiazangbu subbasin southeast of Mt. Geladandong, where widespread continuous permafrost is present.

Subsidence in the Serling Co watershed is normally between 5 and $20 \mathrm{~mm} / \mathrm{a}$ (see the statistical details in Table 8) and reaches $50 \mathrm{~mm} / \mathrm{a}$ in certain regions, reflecting high excess ice and rapid ice loss in the region. The seasonal amplitude ranges between $0 \mathrm{~mm}$ and $60 \mathrm{~mm}$ within the watershed area. Among the areas with velocities greater than $2.5 \mathrm{~mm} / \mathrm{a}, 0.3 \%$ of them had seasonal amplitudes greater than $30 \mathrm{~mm}, 2.3 \%$ of them had amplitudes between $20 \mathrm{~mm}$ and $30 \mathrm{~mm}, 26.3 \%$ of them had amplitudes between $10 \mathrm{~mm}$ and $20 \mathrm{~mm}$, $30.3 \%$ of them had amplitudes between $5 \mathrm{~mm}$ and $10 \mathrm{~mm}$, and $40.9 \%$ of them had amplitudes of less than 5 $\mathrm{mm}$; the average seasonal amplitude was $7.9 \mathrm{~mm}$.

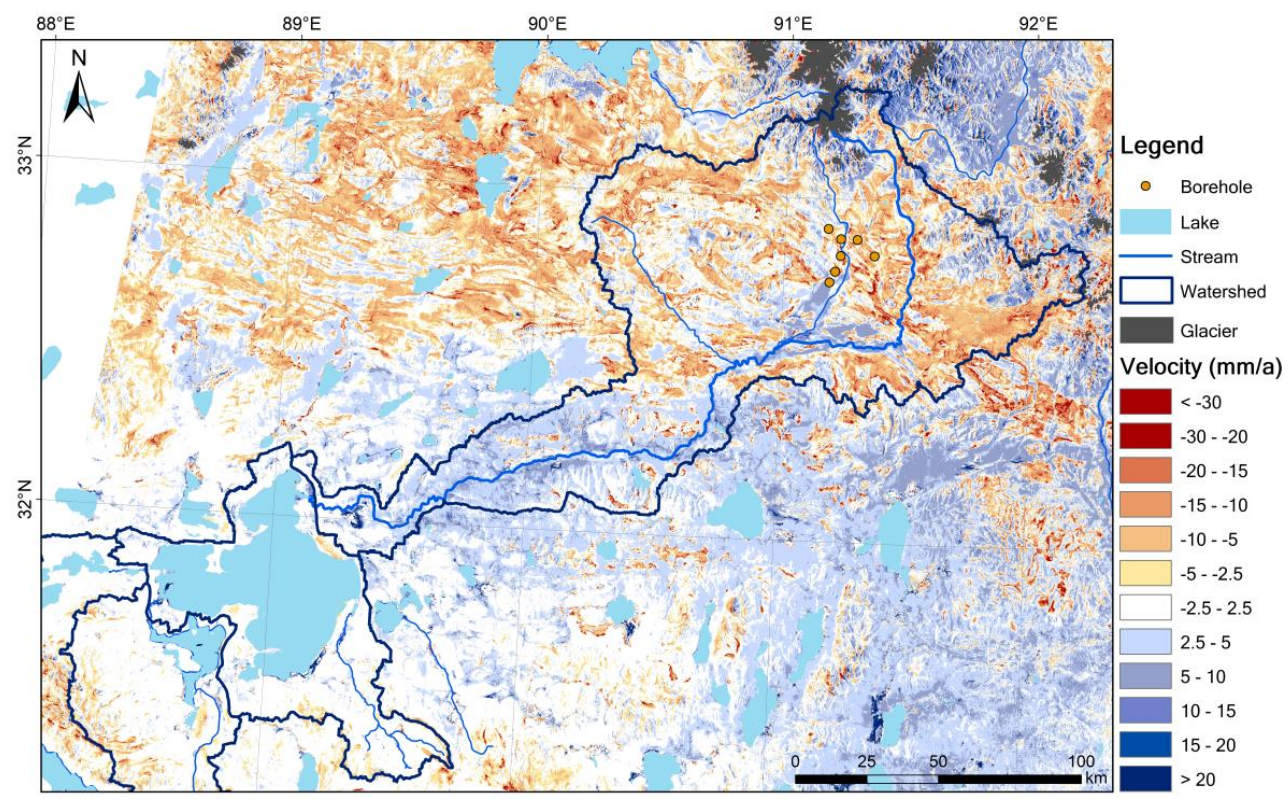

Figure 6 Map of the long-term deformation rate. 


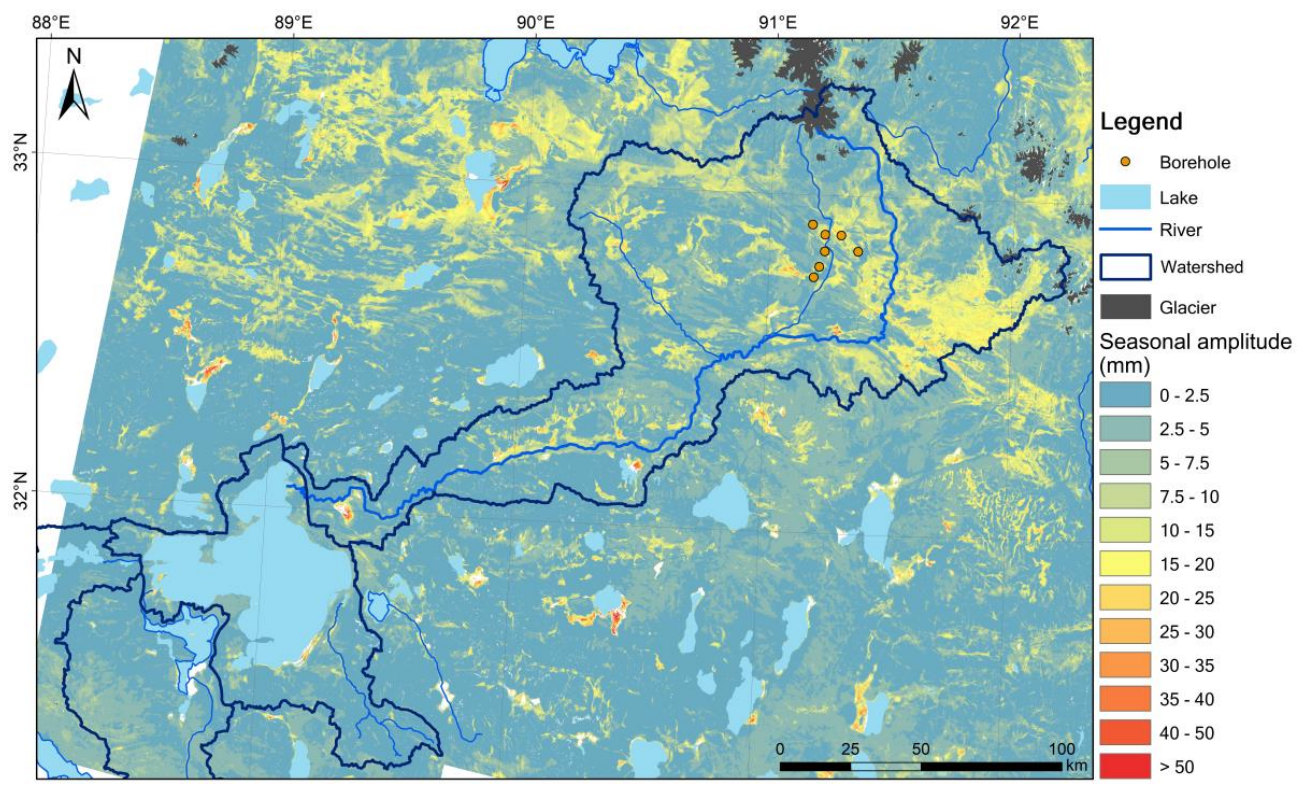

Figure 7 Map of the periodic (seasonal) amplitude.

\subsubsection{Validation with GPR surveying and drilling sites}

385 We also examined the deformation characteristics at the GPR surveying and drilling sites. The deformation time series at seven drilling sites are shown in Fig. 8 and Table 7. The detected deformation properties are highly consistent with the field surveys. Sites SLC03 and SLC04 have the largest seasonal amplitudes of 13.7 $\mathrm{mm}$ and $16.5 \mathrm{~mm}$, respectively, and they are the wettest and have the most developed vegetation cover, i.e., alpine swamp meadows with coverage higher than $90 \%$. These seasonal amplitudes are to a large extent caused by the water-ice phase changes in the freeze-thaw cycle and are thus extremely sensitive to the water content in the active layer(Chen et al., 2020). This sensitivity explains the high seasonal amplitudes at SLC03 and SLC04. Permafrost can hold more water in the active layer than seasonally frozen ground; this is why site SCL05 of seasonally frozen ground displayed the smallest seasonal oscillation of $1.9 \mathrm{~mm}$. Similarly, among the twenty GPR segments where the existence of surface permafrost was confirmed, the seasonal amplitudes were all larger than $3.3 \mathrm{~mm}$, with the largest amplitude of $19.9 \mathrm{~mm}$ and an average of $8.4 \mathrm{~mm}$.

Excess ice was found in the SLC04 borehole; correspondingly, the largest subsidence velocity of $17.3 \mathrm{~mm} / \mathrm{a}$ was observed at this site. Likewise, SLC02, SLC03, and SLC03, in which ground ice was found, all showed different levels of subsidence. Site SLC05, which is seasonally frozen and located in a river valley between two rivers, exhibited a uplift of $5.4 \mathrm{~mm} / \mathrm{a}$, which might be because of sedimentation. 

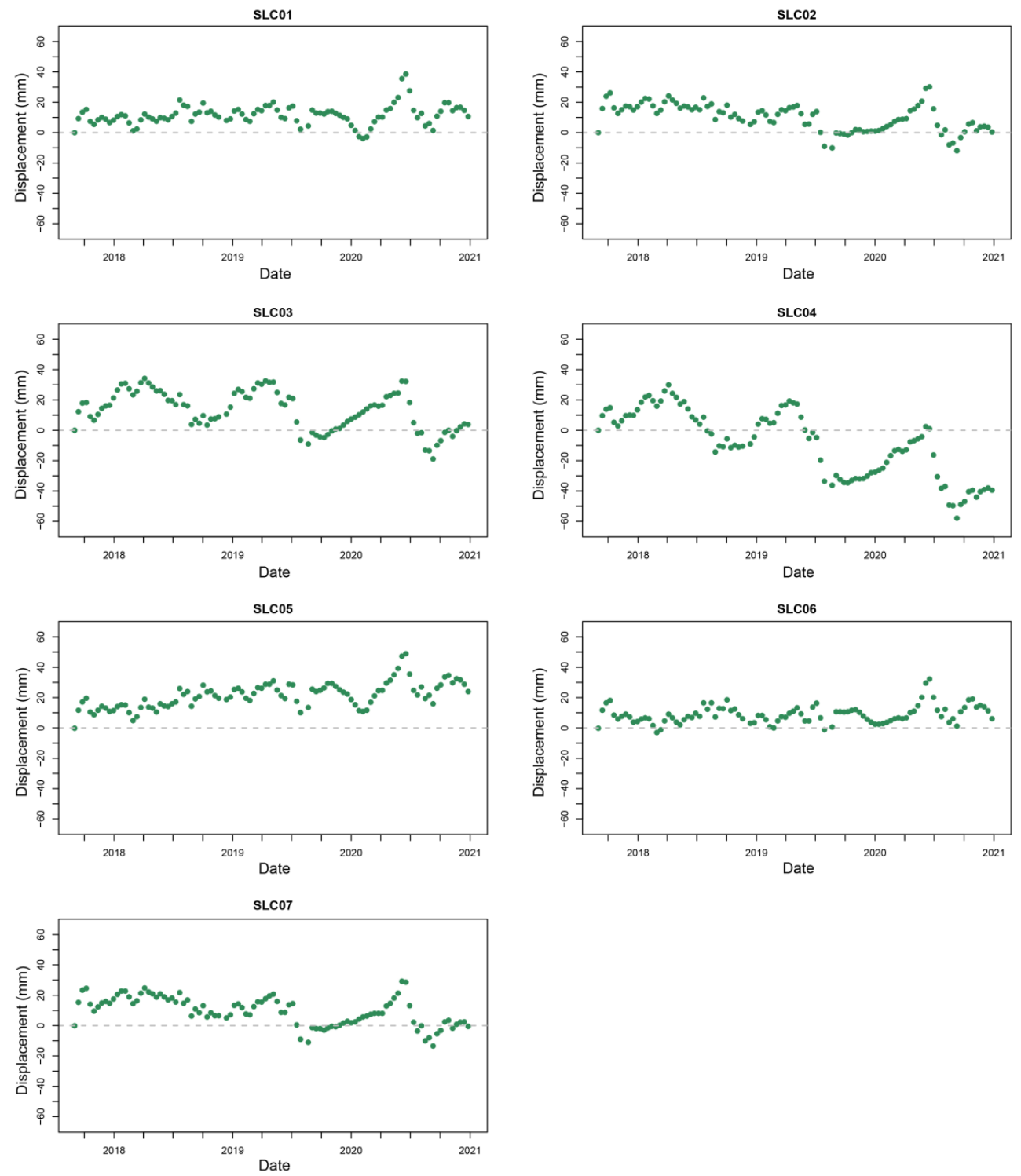

Figure 8 Deformation time series at seven drilling sites.

Table 7 Deformation properties at seven borehole sites.

\begin{tabular}{lll}
\hline Site & Periodic seasonal oscillation $(\mathbf{m m})$ & Deformation rate $(\mathbf{m m} / \mathbf{a})$ \\
\hline SLC01 & 3.0 & 1.4 \\
\hline SLC02 & 5.0 & -5.1 \\
\hline SLC03 & 13.7 & -5.6 \\
\hline SLC04 & 16.5 & -17.3 \\
\hline
\end{tabular}




\begin{tabular}{lll}
\hline SLC05 & 1.9 & 5.4 \\
\hline SLC06 & 3.5 & 1.5 \\
\hline SLC07 & 6.9 & -5.4 \\
\hline
\end{tabular}

\subsection{Water contribution from ground ice melting}

Fig. 9 shows the map of the potential water contribution caused by permafrost ground ice change. Table 9 lists the statistics of the potential water contribution volume for the Serling Co basin. The main contribution comes from the Zhajiazangbu subbasin, where the permafrost coverage is $66.2 \%$, and the contribution from the Boquzangbu subbasin is very limited. The potential rate at which ground ice meltwater is generated was $55.4 \times 10^{6} \mathrm{~m}^{3} / \mathrm{a}$ in the Zhajiazangbu subbasin and $0.6 \times 10^{6} \mathrm{~m}^{3} / \mathrm{a}$ in the Boquzangbu subbasin, and the overall amount is $56.0 \times 10^{6} \mathrm{~m}^{3} / \mathrm{a}$. Compared to the Serling Co water storage change velocity of $496.3 \times 10^{6} \mathrm{~m}^{3} / \mathrm{a}$, we obtained a ground ice melting water release contribution ratio of $11.3 \%$. If the potential water contribution volume is converted to the runoff depth in the watershed extent, this value corresponds to a $2.6 \mathrm{~mm} / \mathrm{a}$ increase in the runoff depth.

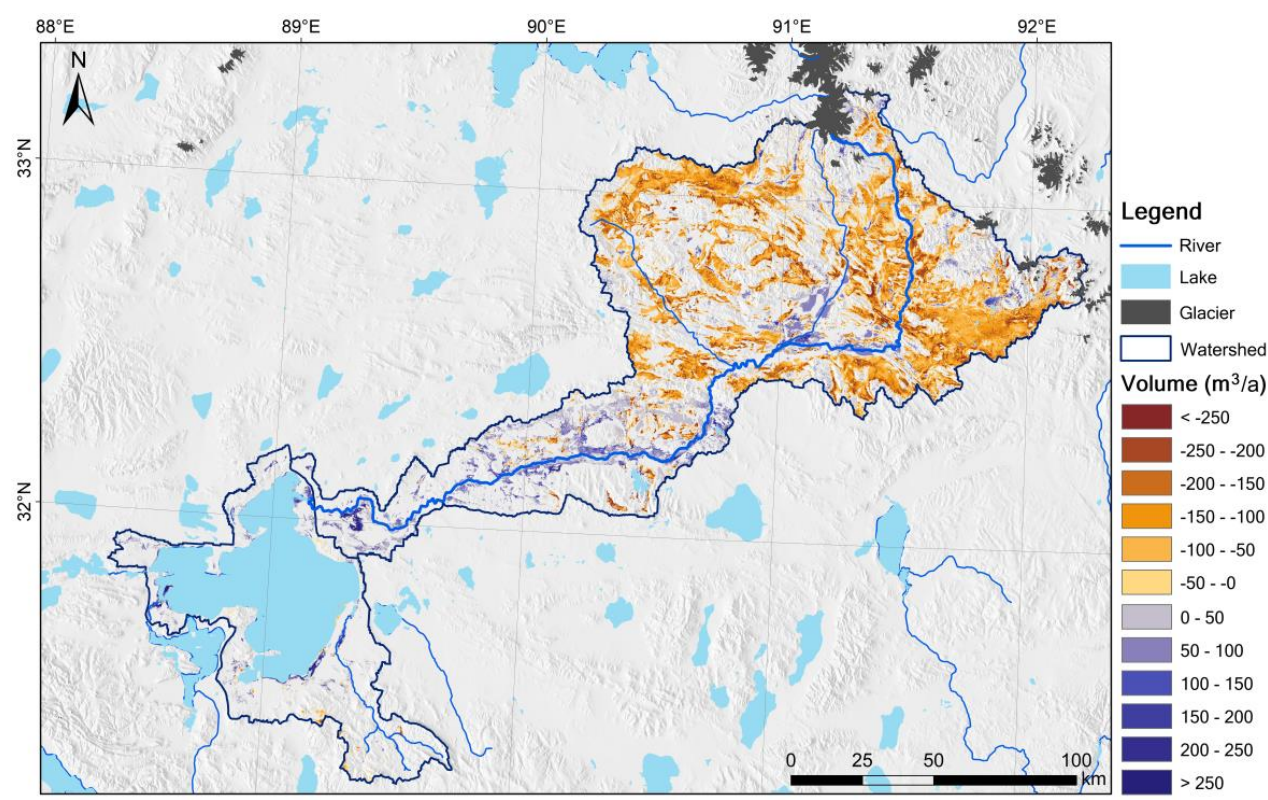

Figure 9 Map of the potential water volume from ground ice change. The grid color represents the potential water contribution volume for the grid cell. Negative values indicate ground ice loss and water release.

420 We also considered two extreme situations when taking into account the ground surface uplift signals. If we assume all the uplift signals were caused by permafrost ground ice aggradation, thereby subtracting $14.6 \times 10^{6}$ $\mathrm{m}^{3} / \mathrm{a}$ from $56.0 \times 10^{6} \mathrm{~m}^{3} / \mathrm{a}$, then a water contribution volume of $41.4 \times 10^{6} \mathrm{~m}^{3} / \mathrm{a}$ is finally calculated and 

the runoff depth at the watershed scale, this value corresponds to a $1.9 \mathrm{~mm} / \mathrm{a}$ increase in the runoff depth. If we assume all the uplift signals were caused by the rise of the groundwater table, which is recharged by melting of ground ice infiltration, then a water contribution volume of $70.6 \times 10^{6} \mathrm{~m}^{3} / \mathrm{a}$ is finally calculated and represents $14.2 \%$ of the lake water storage change and a $3.3 \mathrm{~mm} / \mathrm{a}$ increase in the runoff depth. Table 9 lists the water contribution of ground ice melting, as well as the extreme values when taking into account the signals of ground surface uplift.

\subsection{Uncertainty analysis}

\subsubsection{Uncertainties and accuracies of lake volume change}

Fig. 4(a) clearly shows the water surface elevation of Serling Co lake is increasing gradually, although the seasonal fluctuation is evident as well. Serling Co lake has 49 acquisitions of ICESat-2 dataset during the investigation period, and $69.4 \%$ of acquisitions has a standard deviation of elevation measurements smaller than $0.05 \mathrm{~m}$ within the lake, as shown in Fig. 4(d). It means that the average values of all elevation measurements within the lake could represent the lake's elevation on a given date. To evaluate the accuracy of lake area extent, we validated the classification results by randomly selecting 1000 pixels on Landsat images and visually examined the classification results. It shows that the classification accuracies reach around 0.98 .

Our analysis shows that during the period 2018-2020, the water level increased at a rate of $0.2 \mathrm{~m} / \mathrm{a}$, the lake area increased at a rate of $10.3 \mathrm{~km}^{2} / \mathrm{a}$, and the lake water storage increased at a rate of $496.3 \times 10^{6} \mathrm{~m}^{3} / \mathrm{a}$. These values were compared to the values recorded in previous studies. The water level remained stable during the period 1972-1999 and then increased at an approximate rate of $1.0 \mathrm{~m} / \mathrm{a}$ in the period 2000-2006, after which the rate of increase gradually slowed down to $0.2 \mathrm{~m} / \mathrm{a}$ during 2007-2011 (Doin et al., 2015). From 1972 to 2017 , there was a $15.6 \mathrm{~km}^{2} / \mathrm{a}$ increase in the lake area and a $425 \times 10^{6} \mathrm{~m}^{3} / \mathrm{a}$ increase in the lake water storage, but the corresponding rates of increase in 1972-2000 were slow at $9.1 \mathrm{~km}^{2} / \mathrm{a}$ and $368 \times 10^{6} \mathrm{~m}^{3} / \mathrm{a}$, respectively, and then they markedly accelerated in 2000-2005, with increases of $60.7 \mathrm{~km}^{2} / \mathrm{a}$ and $1576 \times 10^{6} \mathrm{~m}^{3} / \mathrm{a}$, respectively; after that, in 2005-2017, the rates of increase in the lake area and water storage slowed to only $12.6 \mathrm{~km}^{2} / \mathrm{a}$ and $553 \times 10^{6} \mathrm{~m}^{3} / \mathrm{a}$, respectively (Yang et al., 2017; Zhu et al., 2019). The values retrieved in this study are all in the range of historical values and closest to the values during the 2010s.

\subsubsection{Uncertainties and accuracies of deformation}

455 1) Uncertainties in long-term deformation velocity estimation

The standard deviation of the long-term deformation velocity parameter in Eq. (2) is applied to represent the uncertainties of the long-term deformation velocity estimation (Chen et al., 2018; Zhang et al., 2019b). Fig. 


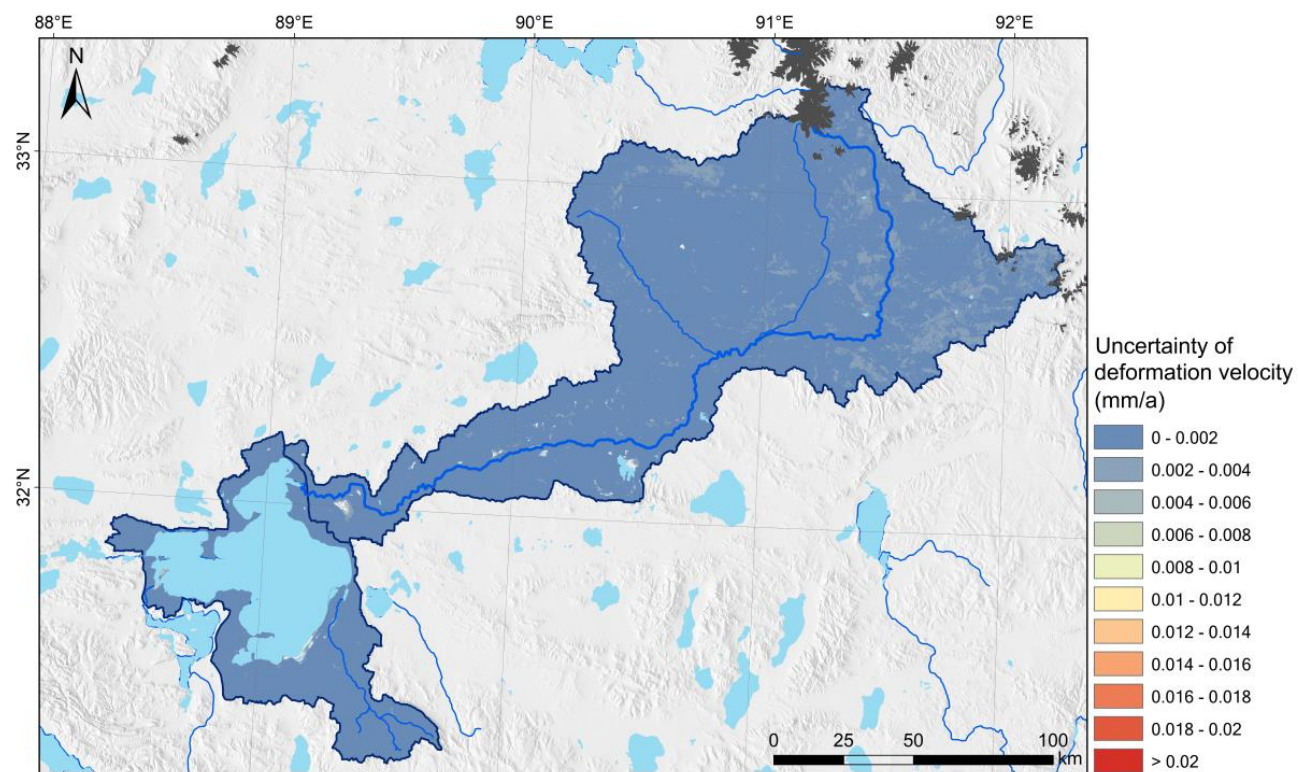

Figure 10 Uncertainty of long-term deformation velocity.

2) Accuracy of In-SAR derived deformation velocity

In this study, the deformation characteristics were compared with the characteristics of boreholes, and excellent agreement was achieved. We also validated the SBAS-InSAR-derived deformation, which has the same processing flow as applied in this study, with the in situ leveling measurements at the Wudaoliang site on the Tibetan Plateau; the relative error is $14.8 \%$ regarding the long-term deformation rate (Zhou et al., 2019). Furthermore, we are currently deploying an automatic deformation monitoring device in the watershed, and it is expected to provide an independent validation reference in the watershed.

\subsubsection{Uncertainties of slope angle threshold in ground ice meltwater estimation}

During the estimation process, we masked out regions with slopes steeper than the threshold of 10 degrees. We also tested the impact on the results of setting slope thresholds of 15 degrees and 20 degrees. When using the 15 degree threshold or the 20 degree threshold, the water release volume changed by less than $1 \%$. Hence, the setting of the threshold does not greatly influence the final results. 


\section{Discussion \\ 5.1 Uplift displacement signal}

Previous research normally focuses on the thaw subsidence signal on the Tibetan Plateau, and less attention has been given to the uplift signal. Ground uplift was detected in the sporadic permafrost environment in the middle stream of the Zhajiazangbu subbasin and in some places around Serling Co lake, especially in drained ponds. It is also detected in the cold environment in the upstream portion of the Zhajiazangbu subbasin, where permafrost terrain is widely subsiding. Some of the uplift signals might be related to sedimentation or the rise of the groundwater table; in addition, some of these uplift signals might be caused by ground ice aggradation, as in these areas, the water supply is sufficient and the periodic seasonal deformation amplitude is large. Ground ice aggradation is slightly surprising in the overall warming climate of the study area. However, the upward freezing of previously unfrozen (or seasonally frozen) sediment is still possible and may occur because of sediment accretion (e.g., deltaic and alluvial sedimentation) (French, 2017). In our study area, the terrain uplift signals were found mainly near the rivers in a sedimentation landscape. A previous study (Daout et al., 2020) also detected a complex deformation signal in the permafrost on the northeastern Tibetan Plateau and hypothesized that the uplift deformation in lowland regions was caused by excess meltwater pooling, which triggered an increase in the segregation of ice near the permafrost table. Thus, on the Tibetan Plateau, it might be common for degradation and aggradation of ground ice to both occur in permafrost environments, with degradation representing the dominant pattern and aggradation existing in local areas. Currently, most studies focus on permafrost subsidence signals, and few studies have studied permafrost ground ice aggradation and the causes of uplift signals in local environments. Nevertheless, the uplift signals in the permafrost environment on the Tibetan Plateau are worthy of additional research, and further details on the Serling Co basin are expected to be unveiled and supplemented by the next field survey.

\subsection{Water contribution from permafrost ground ice melting in the Serling Co watershed}

In this study, we assumed that water released by permafrost ice melt will eventually enter Serling Co lake, and the potential water contribution was estimated. The effect of permafrost degradation on the terrestrial water cycle is complicated (Ma et al., 2020). The gradually thickening active layer may hold more water in the soil layer; thus, endorheic basins may collect more water during the thawing season. Additionally, the increase in the active layer thickness due to the warming climate could lead to more evaporation. In permafrost terrain, the interaction between groundwater and surface water is restricted. With permafrost degradation, groundwater recharge and discharge rates are expected to increase since the impermeable effect of permafrost weakens. Melting of ground ice can lead to more surface water infiltration into groundwater in the basin, resulting in an increase in groundwater storage in the basin (Bense et al., 2012; Zhang et al., 2017).

Based on the detected deformation, we estimated that the volumetric rate of water release due to the melting of ground ice could reach $56.0 \times 10^{6} \mathrm{~m}^{3} / \mathrm{a}$ for the Zhajiazangbu and Boquzangbu subbasins. If the Alizangbu 
the proposed method can be easily extended to other watersheds underlain by permafrost and can help understand the hydrologic changes in these watersheds.

\section{Acknowledgments}

This work was supported by research grants from the National Natural Science Foundation of China (No. 42001054 and 41931180), the Second Tibetan Plateau Scientific Expedition and Research (STEP) program (No. 2019QZKK0201), and the Natural Science Foundation of the Jiangsu Province (BK20200828). We are also grateful to the logistics staff who provided tremendous help during the field campaign.

\section{Data availability}

Sentinel-1 Level 1 single-look complex (SLC) images can be accessed from the Alaska Satellite Facility (https://search.asf.alaska.edu/) or Copernicus Open Access Hub (https://scihub.copernicus.eu/). The lake area extents during 2015-2017 were from the datasets "The lakes larger than $1 \mathrm{~km}^{2}$ in Tibetan Plateau (V2.0)", provided by the National Tibetan Plateau Data Center.

\section{Author contribution}

L. Wang and L. Zhao designed the study and wrote the manuscript. L. Zhao directed the project. L. Wang,

H. Zhou, S. Liu, and C. Li performed the surface deformation analysis; X. Li performed the lake water level analysis; E. Du conducted GPR survey and interpretation; L. Zhao, G. Liu, D. Zou, H. Zhou, Z. Sun, E. Du, Y. Xiao, G. Hu, S. Liu, Z. Li, C. Wang, Y Qiao and T. Wu conducted the field works and borehole drillings.

\section{Competing interests}

No conflict of interest.

\section{References}

Bense, V., Kooi, H., Ferguson, G., and Read, T.: Permafrost degradation as a control on hydrogeological regime shifts in a warming climate, Journal of Geophysical Research: Earth Surface, 117, 2012.

Berardino, P., Fornaro, G., Lanari, R., and Sansosti, E.: A new algorithm for surface deformation monitoring based on small baseline differential SAR interferograms, Geoscience and Remote Sensing, IEEE Transactions on, 40, 2375-2383, 2002.

Bian, D., Bian, B., La, B., Wang, C., and Chen, T.: The response of water level of Selin Co to climate change during 1975-2008 (in Chinese), Journal of Geographical Sciences, 65, 313-319, 2010

575 Buckel, J., Reinosch, E., Hördt, A., Zhang, F., Riedel, B., Gerke, M., Schwalb, A., and Mäusbacher, R.: Insights into a remote cryosphere: a multi-method approach to assess permafrost occurrence at the Qugaqie basin, western Nyainqêntanglha Range, Tibetan Plateau, The Cryosphere, 15, 149-168, 2021.

Chen, J., Liu, L., Zhang, T., Cao, B., and Lin, H.: Using persistent scatterer interferometry to map and quantify permafrost thaw subsidence: A case study of Eboling Mountain on the Qinghai -Tibet Plateau, Journal of Geophysical Research: Earth Surface, 123, 2663-2676, 2018.

Chen, J., Wu, Y., O'Connor, M., Cardenas, M. B., Schaefer, K., Michaelides, R., and Kling, G.: Active layer freeze-thaw and water storage dynamics in permafrost environments inferred from InSAR, Remote Sensing of Environment, 248, 112007, 2020. 
Cheng, G.: The mechanism of repeated-segregation for the formation of thick layered ground ice, Cold Regions Science and Technology, 8, 57-66, 1983.

585 Daout, S., Dini, B., Haeberli, W., Doin, M.-P., and Parsons, B.: Ice loss in the Northeastern Tibetan Plateau permafrost as seen by 16 yr of ESA SAR missions, Earth and Planetary Science Letters, 545, 116404, 2020.

Daout, S., Doin, M. P., Peltzer, G., Socquet, A., and Lasserre, C.: Large-scale InSAR monitoring of permafrost freeze-thaw cycles on the Tibetan Plateau, Geophysical Research Letters, 44, 901-909, 2017.

590 Doin, M. P., Twardzik, C., Ducret, G., Lasserre, C., Guillaso, S., and Jianbao, S.: InSAR measurement of the deformation around $5310,2015$.

Fattahi, H. and Amelung, F.: DEM error correction in InSAR time series, IEEE Transactions on Geoscience and Remote Sensing, 51, 4249-4259, 2013.

French, $\mathrm{H}$ and Harbor, J: 8.1 The Development and History of Glacial and Periglacial Geomorphology, Treatise on Geomorphology, Academic Press, https://doi.org/10.1016/B978-0-12-374739-6.00190-1, 2013.

French, H. M.: The periglacial environment, John Wiley \& Sons2017.

Guarnieri, A. M. and Tebaldini, S.: On the exploitation of target statistics for SAR interferometry applications, IEEE Transactions on Geoscience and Remote Sensing, 46, 3436-3443, 2008.

Günther, F., Overduin, P. P., Yakshina, I. A., Opel, T., Baranskaya, A. V., and Grigoriev, M. N.: Observing Muostakh disappear:

600 permafrost thaw subsidence and erosion of a ground-ice-rich island in response to arctic summer warming and sea ice reduction, The Cryosphere, 9, 151-178, 2015.

Guo, Y., Zhang, Y., Ma, N., Xu, J., and Zhang, T.: Long-term changes in evaporation over Siling Co Lake on the Tibetan Plateau and its impact on recent rapid lake expansion, Atmospheric research, 216, 141-150, 2019.

Jolivet, R., Agram, P. S., Lin, N. Y., Simons, M., Doin, M. P., Peltzer, G., and Li, Z.: Improving InSAR geodesy using global atmospheric models, Journal of Geophysical Research: Solid Earth, 119, 2324-2341, 2014.

Kokelj, S. V. and Jorgenson, M.: Advances in thermokarst research, Permafrost and Periglacial Processes, 24, 108-119, 2013.

Lanari, R., Lundgren, P., Manzo, M., and Casu, F.: Satellite radar interferometry time series analysis of surface deformation for Los Angeles, California, Geophysical Research Letters, 31, 2004.

Lantuit, H. and Pollard, W.: Fifty years of coastal erosion and retrogressive thaw slump activity on Herschel Island, southern

610 Beaufort Sea, Yukon Territory, Canada, Geomorphology, 95, 84-102, 2008.

Lei, Y., Yao, T., Bird, B. W., Yang, K., Zhai, J., and Sheng, Y.: Coherent lake growth on the central Tibetan Plateau since the 1970s: Characterization and attribution, Journal of Hydrology, 483, 61-67, 2013.

Lei, Y., Yang, K., Wang, B., Sheng, Y., Bird, B. W., Zhang, G., and Tian, L.: Response of inland lake dynamics over the Tibetan Plateau to climate change, Climatic Change, 125, 281-290, 2014.

615 Li, Y., Liao, J., Guo, H., Liu, Z., and Shen, G.: Patterns and potential drivers of dramatic changes in Tibetan lakes, 1972-2010, PloS one, 9, e111890, 2014.

Li, Z., Zhao, R., Hu, J., Wen, L., Feng, G., Zhang, Z., and Wang, Q.: InSAR analysis of surface deformation over permafrost to estimate active layer thickness based on one-dimensional heat transfer model of soils, Scientific reports, 5, 2015.

Liu, L., Schaefer, K., Zhang, T., and Wahr, J.: Estimating 1992-2000 average active layer thickness on the Alaskan North Slope from remotely sensed surface subsidence, Journal of Geophysical Research: Earth Surface, 117, 2012.

Lu, P., Han, J., Li, Z., Xu, R., Li, R., Hao, T., and Qiao, G.: Lake outburst accelerated permafrost degradation on Qinghai-Tibet Plateau, Remote Sensing of Environment, 249, 112011, 2020.

Ma, Q., Jin, H.-J., Bense, V. F., Dong-Liang, L., Marchenko, S. S., Harris, S. A., and Lan, Y.-C.: Impacts of degrading permafrost on streamflow in the source area of Yellow River on the Qinghai-Tibet Plateau, China, Advances in Climate Change Research, 2020.

625 Mackay, J. R.: Downward water movement into frozen ground, western arctic coast, Canada, Canadian Journal of Earth Sciences, 20, 120-134, 1983.

Qiao, B., Zhu, L., and Yang, R.: Temporal-spatial differences in lake water storage changes and their links to climate change throughout the Tibetan Plateau, Remote Sensing of Environment, 222, 232-243, 2019.

Reinosch, E., Buckel, J., Dong, J., Gerke, M., Baade, J., and Riedel, B.: InSAR time series analysis of seasonal surface displacement dynamics on the Tibetan Plateau, The Cryosphere, 14, 1633-1650, 2020.

Shi, Y., Liu, C., and Wang, Z.: Concise Glacier Inventory of China Shanghai Popular Science Press, Shanghai, 89-100 pp.2005.

Shiklomanov, N. I., Streletskiy, D. A., Little, J. D., and Nelson, F. E.: Isotropic thaw subsidence in undisturbed permafrost landscapes, Geophysical Research Letters, 40, 6356-6361, 2013.

Song, C., Huang, B., Richards, K., Ke, L., and Hien Phan, V.: Accelerated lake expansion on the Tibetan Plateau in the 2000s: Induced by glacial melting or other processes?, Water Resources Research, 50, 3170-3186, 2014.

Streletskiy, D. A., Shiklomanov, N. I., Little, J. D., Nelson, F. E., Brown, J., Nyland, K. E., and Klene, A. E.: Thaw subsidence in undisturbed tundra landscapes, Barrow, Alaska, 1962-2015, Permafrost and Periglacial Processes, 28, 566-572, 2016. Tong, K., Su, F., and Xu, B.: Quantifying the contribution of glacier meltwater in the expansion of the largest lake in Tibet, Journal of Geophysical Research: Atmospheres, 121,11,158-111,173, 2016.

640 Tough, J., Blacknell, D., and Quegan, S.: A statistical description of polarimetric and interferometric synthetic aperture radar data, Proceedings of the Royal Society of London. Series A: Mathematical and Physical Sciences, 449, 567-589, 1995.

Usai, S.: A least squares database approach for SAR interferometric data, Geoscience and Remote Sensing, IEEE Transactions on, 41, 753-760, 2003.

Wan, W., Long, D., Hong, Y., Ma, Y., Yuan, Y., Xiao, P., Duan, H., Han, Z., and Gu, X.: A lake data set for the Tibetan Plateau from the

6451960 s, 2005, and 2014, Scientific data, 3, 1-13, 2016.

Wu, Z., Zhao, L., Liu, L., Zhu, R., Gao, Z., Qiao, Y., Tian, L., Zhou, H., and Xie, M.: Surface-deformation monitoring in the permafrost regions over the Tibetan Plateau, using Sentinel-1 data, Sciences in Cold and Arid Regions, 10, 114-125, 2018.

Yang, R., Zhu, L., Wang, J., Ju, J., Ma, Q., Turner, F., and Guo, Y.: Spatiotemporal variations in volume of closed lakes on the Tibetan Plateau and their climatic responses from 1976 to 2013, Climatic Change, 140, 621-633, 2017. 
650 Yang, Y., Wu, Q., Yun, H., Jin, H., and Zhang, Z.: Evaluation of the hydrological contributions of permafrost to the thermokarst lakes on the Qinghai-Tibet Plateau using stable isotopes, Global and planetary change, 140, 1-8, 2016.

Yang, Y., Wu, Q., Jin, H., Wang, Q., Huang, Y., Luo, D., Gao, S., and Jin, X.: Delineating the hydrological processes and hyd raulic connectivities under permafrost degradation on Northeastern Qinghai-Tibet Plateau, China, Journal of hydrology, 569, 359-372, 2019.

655 Zhang, G.: The lakes larger than $1 \mathrm{~km} 2$ in Tibetan Plateau (V2.0) (1970s-2018) [dataset], 10.11888/Hydro.tpdc.270303, 2019. Zhang, G., Chen, W., and Xie, H.: Tibetan Plateau's lake level and volume changes from NASA's ICESat/ICESat-2 and Landsat Missions, Geophysical Research Letters, 46, 13107-13118, 2019a.

Zhang, G., Yao, T., Shum, C., Yi, S., Yang, K., Xie, H., Feng, W., Bolch, T., Wang, L., and Behrangi, A.: Lake volume and groundwater storage variations in Tibetan Plateau's endorheic basin, Geophysical Research Letters, 44, 5550-5560, 2017.

660 Zhang, G., Yao, T., Xie, H., Yang, K., Zhu, L., Shum, C., Bolch, T., Yi, S., Allen, S., and Jiang, L.: Response of Tibetan Plateau's lakes to climate changes: trend, pattern, and mechanisms, Earth-Science Reviews, 103269, 2020.

Zhang, Y., Fattahi, H., and Amelung, F.: Small baseline InSAR time series analysis: Unwrapping error correction and noise reduction, Computers \& Geosciences, 133, 104331, $2019 \mathrm{~b}$.

665 China2019.

Zhao, L., Hu, G., Zou, D., Wu, X., Ma, L., Sun, Z., Yuan, L., Zhou, H., and Liu, S.: Permafrost Changes and Its Effects on Hydrological Processes on Qinghai-Tibet Plateau (in Chinese), Bulletin of the Chinese Academy of Sciences, 34, 1233-1246, 2019.

Zhao, L., Zou, D., Du, E., Hu, G., Pang, Q., Xiao, Y., Li, R., Sheng, Y., Wu, X., Sun, Z., Wang, L., Wang, C., Ma, L., Zhou, H., and Liu, S.: Changing climate and the permafrost environment on the Qinghai-Tibet (Xizang) Plateau, Permafrost and Periglacial Processes, $670 \quad 10.1002 /$ ppp.2056, 2020.

Zhou, H., Zhao, L., Tian, l., Wu, Z., Xie, M., Yuan, L., Ni, J., Qiao, Y., Gao, Z., and Shi, J.: Monitoring and analysis of surface deformation in the permafrost area of Wudaoliang on the Tibetan Plateau based on Sentinel-1 data (in Chinese), Journal of Glaciology and Geocryology, 41, 525-536, 2019.

675 the Serling Co region of Tibet over a variety of timescales, Science Bulletin, 64, 422-424, 2019.

Zou, D., Zhao, L., Yu, S., Chen, J., Hu, G., Wu, T., Wu, J., Xie, C., Wu, X., and Pang, Q.: A new map of permafrost distribution on the Tibetan Plateau, The Cryosphere, 11, 2527, 2017.

Zwieback, S. and Meyer, F. J.: Top-of-permafrost ground ice indicated by remotely sensed late-season subsidence, The 680 Cryosphere, 15, 2041-2055, 2021.

Table 8 Characteristics of terrain subsidence in the Serling Co basin.

\begin{tabular}{|c|c|c|c|c|c|c|}
\hline \multirow[t]{2}{*}{ Basin } & \multirow{2}{*}{$\begin{array}{l}\text { Average } \\
(\mathrm{mm})\end{array}$} & \multicolumn{5}{|c|}{ Percentage of subsidence levels $(\%)$} \\
\hline & & $\begin{array}{l}-5 \sim-2.5 \\
\mathrm{~mm}\end{array}$ & $\begin{array}{l}-10 \sim-5 \\
\mathrm{~mm}\end{array}$ & $\begin{array}{l}-20 \sim-10 \\
\mathrm{~mm}\end{array}$ & $\begin{array}{l}-30 \sim-20 \\
\mathrm{~mm}\end{array}$ & $<-30 \mathrm{~mm}$ \\
\hline $\begin{array}{l}\text { Zhajiazangbu } \\
\text { subbasin }\end{array}$ & -9.1 & 22.4 & 43 & 30.7 & 3.5 & 0.4 \\
\hline $\begin{array}{l}\text { Boquzangbu } \\
\text { subbasin }\end{array}$ & -5.7 & 58.6 & 30.7 & 9.7 & 0.9 & 0.1 \\
\hline Overall & -9 & 23.4 & 42.6 & 30.2 & 3.4 & 0.4 \\
\hline
\end{tabular}

Table 9 Potential water contribution of ground ice melting.

\begin{tabular}{lll}
\hline Basin & Water volume $\left(10^{6} \mathrm{~m}^{3} / \mathrm{a}\right)$ & Runoff depth $(\mathrm{mm})$
\end{tabular}


https://doi.org/10.5194/tc-2021-335

Preprint. Discussion started: 22 November 2021

(c) Author(s) 2021. CC BY 4.0 License.

The Cryosphere

\begin{tabular}{|c|c|c|c|c|c|c|c|}
\hline & $\begin{array}{l}\text { subsidence } \\
\text { signal }\end{array}$ & $\begin{array}{l}\text { uplift } \\
\text { signal }\end{array}$ & $\begin{array}{l}\text { after } \\
\text { balance }^{1}\end{array}$ & $\begin{array}{l}\text { after } \\
\text { balance }^{2}\end{array}$ & $\begin{array}{l}\text { Water released by } \\
\text { melting of ground ice }\end{array}$ & $\begin{array}{l}\text { after } \\
\text { balance }^{1}\end{array}$ & $\begin{array}{l}\text { after } \\
\text { balance }^{2}\end{array}$ \\
\hline $\begin{array}{l}\text { Zhajiazangbu } \\
\text { subbasin }\end{array}$ & 55.4 & 11.8 & 43.6 & 67.2 & 3.4 & 2.7 & 4.2 \\
\hline $\begin{array}{l}\text { Boquzangbu } \\
\text { subbasin }\end{array}$ & 0.6 & 2.7 & -2.1 & 3.4 & 0.1 & -0.4 & 0.6 \\
\hline Overall & 56.0 & 14.6 & 41.4 & 70.6 & 2.6 & 1.9 & 3.3 \\
\hline
\end{tabular}

increasement

690 "after balance" " assumes all the uplift signals were caused by permafrost ground ice aggradation, thereby subtracting from the value of the subsidence signal.

"after balance ${ }^{2 "}$ " assumes all the uplift signals were caused by the rise of the groundwater table, which is recharged by melting of ground ice infiltration, thereby adding to the value of the subsidence signal. 